\title{
Inhibitory effects of docosyl $p$-coumarate on DNA topoisomerase activity and human cancer cell growth
}

\author{
YOSHIYUKI MIZUSHINA ${ }^{1,2}$, KATSUMI NISHIMURA $^{3}$, YUKIKO TAKENAKA $^{3}$, TOSHIFUMI TAKEUCHI ${ }^{4}$, \\ FUMIO SUGAWARA $^{4}$, HIROMI YOSHIDA ${ }^{1,2}$ and TAKAO TANAHASHI ${ }^{3}$ \\ ${ }^{1}$ Laboratory of Food \& Nutritional Sciences, Department of Nutritional Science, Kobe-Gakuin University, \\ Nishi-ku, Kobe, Hyogo 651-2180; ${ }^{2}$ Cooperative Research Center of Life Sciences, Kobe-Gakuin University, \\ Chuo-ku, Kobe, Hyogo 650-8586; ${ }^{3}$ Kobe Pharmaceutical University, Higashinada-ku, Kobe 658-8558; \\ ${ }^{4}$ Department of Applied Biological Science, Tokyo University of Science, Noda, Chiba 278-8510, Japan
}

Received April 9, 2010; Accepted June 14, 2010

DOI: 10.3892/ijo_00000750

\begin{abstract}
We previously found six compounds of alkyl $p$ coumarates from a composite plant Artemisia апnиа L., and chemically synthesized these compounds (cis-isomer of C20, $\mathrm{C} 22$ and $\mathrm{C} 24$, and trans-isomer of $\mathrm{C} 20, \mathrm{C} 22$ and $\mathrm{C} 24$ of $p$ coumarates are compounds $1-6$, respectively). This report describes the inhibitory activities of these alkyl $p$-coumarates against DNA polymerase (pol), DNA topoisomerase (topo), and human cancer cell growth. Among the compounds tested, compounds 1 and 4 weakly inhibited repair-related pol $\beta$ activity, but no compound influenced the activity of replicative pol $\alpha$. Compounds 4-6 and compounds 2 and 5 were potent inhibitors of human topos I and II, respectively. Compounds $2,4,5$ and 6 also suppressed the growth of human colon carcinoma cell line, HCT116, with or without p53, suggesting that cell growth inhibition had the same tendency as the inhibition of topos rather than pols. Compound 5 (docosyl $p$-coumarate), which was the strongest inhibitor of topo II and cancer cell growth in the compounds tested, halted HCT116 $\mathrm{p} 53^{+/+}$cells in $\mathrm{G} 2 / \mathrm{M}$ phases, and induced apoptosis, although
\end{abstract}

Correspondence to: Dr Yoshiyuki Mizushina, Laboratory of Food \& Nutritional Sciences, Department of Nutritional Science, KobeGakuin University, Nishi-ku, Kobe, Hyogo 651-2180, Japan

E-mail: mizushin@nutr.kobegakuin.ac.jp

Abbreviations: pol, DNA-directed DNA polymerase (EC 2.7.7.7); topo, DNA topoisomerase; dsDNA, double-stranded DNA; dTTP, 2'-deoxythymidine 5'-triphosphate; dNTP, 2'-deoxyribonucleotide 5'-triphosphate; DMSO, dimethyl sulfoxide; BSA, bovine serum albumin; SDS, sodium dodecyl sulfate; $\mathrm{IC}_{50}, 50 \%$ inhibitory concentration; $\mathrm{LD}_{50}, 50 \%$ lethal dose; Tm, melting temperature; Clog P, calculated $\log \mathrm{P}$

Key words: alkyl $p$-coumarates, docosyl $p$-coumarate, DNA polymerase, DNA topoisomerase, enzyme inhibitor, cell growth inhibition, cell cycle arrest, apoptosis, p53, anti-cancer agents this compound did not affect the cell cycle of HCT116 $\mathrm{p} 53^{\text {- }}$ cells. These results suggest that the effect of p53-dependent cell cycle arrest may be effective for topo inhibition by compound 5. From these findings, the action mode of alkyl $p$ coumarates as an anti-cancer agent is discussed.

\section{Introduction}

DNA polymerase (pol) catalyzes the addition of deoxyribonucleotides to the 3'-hydroxyl terminus of primed doublestranded DNA (dsDNA) molecules (1). The human genome encodes 14 pols that conduct cellular DNA synthesis (2). Eukaryotic cells reportedly contain three replicative pols $(\alpha$, $\delta$, and $\varepsilon$ ), mitochondrial pol $\gamma$, and at least ten non-replicative pols ( $(\beta, \zeta, \eta, \theta, \iota, \kappa, \lambda, \mu, v$ and REV1) (2-4).

DNA topoisomerases (topos) are key enzymes that control the topological state of DNA. Two classes of topos, type I enzymes, which act by transiently nicking one of the two DNA strands, and type II enzymes, which nick both DNA strands, are dependent on ATP and are involved in many vital cellular processes that influence DNA replication, transcription, recombination, integration and chromosomal segregation (5).

DNA metabolic enzymes, such as pols and topos, are not only essential for DNA replication, repair and recombination, but are also involved in cell division. Selective inhibitors of these enzymes are considered as a group of potentially useful anti-cancer and anti-parasitic agents, because some inhibitors suppress human cancer cell proliferation and are cytotoxic (6-9).

A composite plant Artemisia annua L. is an annual herbaceous plant, which is known in China as a traditional antimalarial medicine, and in Southeast Asia as an anti-pyretic and hemostatic. Previous biological study on the active constituents of A. аппиа disclosed artemisinin, arteannuin $\mathrm{B}$, and many sesquiterpenes as anti-malarial or anti-tumor components (10). We have recently reinvestigated the chemical constituents of A. апnиа to isolate, along with novel sesquiterpenes, esters of $p$-coumaric acid with long-chain alcohols as a mixture of six compounds of different chain length of C20, C22, C24, and cis- and trans-isomers (Fig. 1), and we chemically synthesized these compounds (11). 
The purpose of this study was to find novel bioactivities of these alkyl $p$-coumarates (compounds 1-6). In this report, we investigated the inhibitory activities of these compounds against DNA metabolic enzymes, such as pols and topos, and cellular proliferation processes, such as DNA replication of human large intestine cancer cells (HCT116). It is possible that alkyl $p$-coumarates have anti-cancer activity.

\section{Materials and methods}

Materials. Six alkyl p-coumarates, icosyl cis-p-coumarate (compound 1), docosyl cis-p-coumarate (compound 2), tetracosyl cis-p-coumarate (compound 3), icosyl p-coumarate (compound 4), docosyl $p$-coumarate (compound 5) and tetracosyl $p$-coumarate (compound 6), were chemically synthesized as described previously (11). The chemical structures of the compounds are shown in Fig. 1. Nucleotides and chemically synthesized DNA templates, $\left[{ }^{3} \mathrm{H}\right]$-deoxythymidine 5'-triphosphate (dTTP) $(43 \mathrm{Ci} / \mathrm{mmol})$ and poly $(\mathrm{dA})$, respectively, were purchased from GE Healthcare BioSciences (Little Chalfont, UK). A DNA primer, oligo(dT) ${ }_{18}$, was customized by Sigma-Aldrich Japan K.K. (Hokkaido, Japan). Supercoiled pBR322 plasmid dsDNA was obtained from Takara Bio Inc. (Kyoto, Japan). All other reagents were of analytical grade and were purchased from Nacalai Tesque, Ltd. (Kyoto, Japan).

Enzymes. Pol $\alpha$ was purified from the calf thymus by immunoaffinity column chromatography, as described by Tamai et al (12). Recombinant rat pol $\beta$ was purified from E. coli JMpß5, as described by Date et al (13). The human pol $\gamma$ catalytic gene was cloned into pFastBac, and histidine-tagged enzyme was expressed using the BAC-TO-BAC HT Baculovirus Expression System according to the supplier's manual (Life Technologies, MD, USA) and purified using ProBoundresin (Invitrogen Japan, Tokyo, Japan) (14). Human pols $\delta$ and $\varepsilon$ were purified by the nuclear fractionation of human peripheral blood cancer cells (Molt-4) using the second subunit of pols $\delta$ and $\varepsilon$-conjugated affinity column chromatography, respectively (15). Pol $\alpha$ from a higher plant, cauliflower inflorescence, was purified according to the methods outlined by Sakaguchi et al (16). The Klenow fragment of pol I from E. coli and HIV-1 reverse transcriptase (recombinant) were purchased from Worthington Biochemical Corp. (Freehold, NJ, USA). Taq pol, T4 pol, T7 RNA polymerase and T4 polynucleotide kinase were purchased from Takara (Kyoto, Japan). Calf thymus terminal deoxynucleotidyl transferase and bovine pancreas deoxyribonuclease I were obtained from Stratagene Cloning Systems (La Jolla, CA, USA). Purified human placenta topos I and II were purchased from TopoGen, Inc. (Columbus, OH). Human telomerase was used for the nuclear fractionation of cultured Molt-4 cells.

DNA polymerase assays. The reaction mixtures for pol $\alpha$, pol $\beta$, plant pol $\alpha$ and prokaryotic pols were described previously $(17,18)$, and those for pol $\gamma$, and pols $\delta$ and $\varepsilon$ were as described by Umeda et al (14) and Ogawa et al (19), respectively. For pols, poly $(\mathrm{dA}) / \operatorname{oligo}(\mathrm{dT})_{18}(\mathrm{~A} / \mathrm{T}=2 / 1)$ and dTTP were used as the DNA template-primer and nucleotide (i.e., 2'-deoxyribonucleotide 5'-triphosphates, dNTP) substrate, respectively.
Alkyl p-coumarates (i.e., compounds 1-6) were dissolved in dimethyl sulfoxide (DMSO) at various concentrations and sonicated for $30 \mathrm{sec}$. Aliquots of $4 \mu \mathrm{l}$ of sonicated samples were mixed with $16 \mu 1$ of each enzyme (final amount $0.05 \mathrm{U}$ ) in $50 \mathrm{mM}$ Tris- $\mathrm{HCl}$ (pH 7.5) containing $1 \mathrm{mM}$ dithiothreitol, $50 \%$ glycerol and $0.1 \mathrm{mM}$ EDTA, and kept at $0^{\circ} \mathrm{C}$ for $10 \mathrm{~min}$. These inhibitor-enzyme mixtures $(8 \mu \mathrm{l})$ were added to $16 \mu \mathrm{l}$ of each enzyme standard reaction mixture, and incubated at $37^{\circ} \mathrm{C}$ for $60 \mathrm{~min}$, except for $\mathrm{Taq}$ pol, which was incubated at $74^{\circ} \mathrm{C}$ for $60 \mathrm{~min}$. Activity without the inhibitor was considered $100 \%$, and the remaining activity at each concentration of the inhibitor was determined relative to this value. One unit of pol activity was defined as the amount of enzyme that catalyzed the incorporation of $1 \mathrm{nmol}$ dNTP (i.e., dTTP) into synthetic DNA template-primers in $60 \mathrm{~min}$ at $37^{\circ} \mathrm{C}$ under the normal reaction conditions for each enzyme $(17,18)$.

Measurement of DNA topoisomerase activity. The catalytic activity of topo I was determined by detecting supercoiled plasmid DNA (i.e., form I) in its nicked form (i.e., form II) (20). The topo I reaction was performed in $20 \mu 1$ reaction mixture containing $10 \mathrm{mM}$ Tris- $\mathrm{HCl}$ (pH 7.9), pBR322 DNA (250 ng), $1 \mathrm{mM}$ EDTA, $150 \mathrm{mM} \mathrm{NaCl}, 0.1 \%$ bovine serum albumin (BSA), $0.1 \mathrm{mM}$ spermidine, $5 \%$ glycerol, $2 \mu 1 \mathrm{DMSO}-$ dissolved alkyl $p$-coumarates (i.e., compounds 1-6), and $2 \mathrm{U}$ of topo I. The catalytic activity of topo II was analyzed in the same manner, except that the reaction mixture contained $50 \mathrm{mM}$ Tris- $\mathrm{HCl}\left(\mathrm{pH} \mathrm{8.0)}, 120 \mathrm{mM} \mathrm{KCl}, 10 \mathrm{mM} \mathrm{MgCl}_{2}\right.$, $0.5 \mathrm{mM}$ ATP, $0.5 \mathrm{mM}$ dithiothreitol, supercoiled pBR322 DNA (250 ng) and $2 \mathrm{U}$ of topo II (20). The reaction mixtures were incubated at $37^{\circ} \mathrm{C}$ for $30 \mathrm{~min}$, followed by $1 \%$ sodium dodecyl sulfate (SDS) and $1 \mathrm{mg} / \mathrm{ml}$ proteinase $\mathrm{K}$ digestion, and then $2 \mu \mathrm{l}$ loading buffer was added, consisting of $5 \%$ sarkosyl, $0.0025 \%$ bromophenol blue and $25 \%$ glycerol. To study the binding of the enzyme and DNA based on mobility shifts, SDS denaturation and proteinase $\mathrm{K}$ digestion were omitted. The mixtures were subjected to $1 \%$ agarose gel electrophoresis in TBE (Tris/Borate/EDTA) buffer. Agarose gel was stained with ethidium bromide (EtBr) and DNA was visualized under UV light.

Other enzyme assays. The activities of primase of pol $\alpha$, calf terminal deoxynucleotidyl transferase, human telomerase, HIV-1 reverse transcriptase, T7 RNA polymerase, T4 polynucleotide kinase and bovine deoxyribonuclease I were measured by standard assays according to the manufacturer's specifications, as described by Tamiya-Koizumi et al (21), Mizushina et al (18), Oda et al (22), Ohta et al (23), Nakayama and Saneyoshi (24), Soltis and Uhlenbeck (25), and Lu and Sakaguchi (26), respectively.

Investigation of cytotoxicity on cultured cells. To investigate the effects of alkyl p-coumarates (i.e., compounds 1-6) on cultured human cancer cells, HCT116 human colon carcinoma cell lines with wild-type p53 (HCT116 $\mathrm{p}^{2 /+}$ ) and their isogenic derivatives lacking p53 (HCT116 p53/-) were used. These two cell lines were a kind gift from Dr Bert Vogelstein (Johns Hopkins University, Baltimore). The cells were maintained in McCoy's 5A medium containing 10\% fetal bovine serum (FBS), or in McCoy's 5A-based enriched medium in 
several experiments, adding $10 \% \mathrm{FBS}, 2 \mathrm{mM}$ sodium pyruvate, $50 \mu \mathrm{g} / \mathrm{ml}$ uridine to the former normal medium at $37^{\circ} \mathrm{C}$ with $5 \% \mathrm{CO}_{2}$. The cytotoxicity of the compounds was investigated as follows: high concentrations $(10 \mathrm{mM})$ of the compounds were dissolved in DMSO and stored. Approximately $1 \times 10^{4}$ cells per well were inoculated into 96-well microplates, and then the compound stock solution was diluted to various concentrations and applied to each well. After incubation for $24 \mathrm{~h}$, the survival rate of HCT116 cancer cells was determined by MTT (3-(4,5-dimethylthiazol-2-yl)-2,5-diphenyl tetrazolium bromide) assay (27).

Cell cycle analysis. Cellular DNA content for cell cycle analysis was determined as follows: aliquots of $3 \times 10^{5}$ HCT116 cells (p53 $3^{+/+}$and $\mathrm{p} 53^{-/}$) were harvested into a $35-\mathrm{mm}$ dish, and incubated with medium containing compound 5 for various times. The cells were then washed with ice-cold PBS three times by centrifugation, fixed with $70 \%(\mathrm{v} / \mathrm{v})$ ethanol, and stored at $-20^{\circ} \mathrm{C}$. DNA was stained with PI (3,8-diamino-5-[3(diethylmethylammonio)propyl]-6-phenylphenanthridinium diiodide) staining solution for at least $10 \mathrm{~min}$ at room temperature in the dark. Fluorescence intensity was measured by a FACSCanto flow cytometer in combination with FACSDiVa software [BD (Becton-Dickinson Co.), NJ, USA].

Measurement of caspase-3 activity. The enzymatic activity of caspase- 3 was measured by fluorometric assay. HCT116 p53 $3^{+/+}$and HCT116 p53/- cells $\left(6 \times 10^{5}\right)$ in a $60-\mathrm{mm}$ dish were lysed with RIPA buffer [50 mM Tris- $\mathrm{HCl}(\mathrm{pH} 7.2), 150 \mathrm{mM}$ $\mathrm{NaCl}, 5 \mathrm{mM}$ EDTA, 1\% Nonidet P-40, 0.05\% SDS, $1 \mathrm{mM}$ phenylmethylsulfonyl fluoride (PMSF), and $1 \mathrm{mM}$ leupeptin] and the lysate was centrifuged at $12,000 \mathrm{~g}$ for $15 \mathrm{~min}$. The supernatant was added to the assay buffer [50 mM HEPES (pH 7.4), $100 \mathrm{mM} \mathrm{NaCl}, 1 \mathrm{mM}$ EDTA, $0.1 \%$ CHAPS, $10 \%$ sucrose, and $5 \mathrm{mM}$ dithiothreitol], along with the caspase substrate, Ac-DEVD-MAC and the enzyme reaction was carried out at $30^{\circ} \mathrm{C}$ for $30 \mathrm{~min}$. Cleavage of the substrates was in terms of amino-4-methylcoumarin (AMC) liberation using a microplate reader with a $380 / 460 \mathrm{~nm}$ filter.

\section{Results}

Effects of alkyl p-coumarates on mammalian DNA polymerases $\alpha$ and $\beta$ activity. The chemical structures of alkyl $p$-coumarates (i.e., compounds 1-6), which were chemically synthesized, are shown in Fig. 1. First, the inhibitory activity of calf pol $\alpha$ and rat pol $\beta$ against each compound was investigated. We have been studying selective inhibitors of mammalian pols as useful tools and molecular probes to clarify their biological functions, and to develop chemotherapeutic anti-cancer drug $(9,28)$. In mammalian pols, pol $\alpha$ and pol $\beta$ were used as representative replicative pols and repair/ recombination-related pols, respectively $(2,3)$. No compounds affected the activity of pol $\alpha$ (Table I). Compounds 1 and 4 inhibited pol $B$ activity with $\mathrm{IC}_{50}$ values of 158 and $122 \mu \mathrm{M}$, respectively, but the other compounds had no influence on the activity of pol $\beta$. These results suggest that $\mathrm{C} 18$-alkyl side chain of $p$-coumarates, such as compounds 1 and 4 , must be important for the inhibition of pol $\beta$ activity. As a positive control, we measured the inhibition of these pols
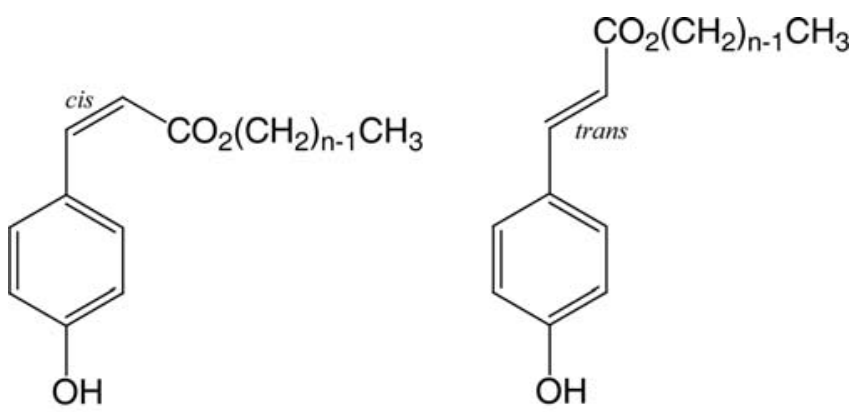

1: $n=20$
2: $n=22$
3: $n=24$

4: $n=20$

$5: n=22$

$6: n=24$

Figure 1. Structures of alkyl p-coumarates. Compound 1, icosyl cis- $p$ coumarate; compound 2, docosyl cis-p-coumarate; compound 3, tetracosyl cis-p-coumarate; compound 4 , icosyl $p$-coumarate; compound 5 , docosyl $p$ coumarate; and compound 6, tetracosyl $p$-coumarate.

Table I. $\mathrm{IC}_{50}$ values of alkyl $p$-coumarates for the activities of mammalian DNA polymerases $\alpha$ and $\beta$.

\begin{tabular}{ccc}
\hline & \multicolumn{2}{c}{$\mathrm{IC}_{50}$ values $(\mu \mathrm{M})$} \\
\cline { 2 - 3 } Compound & Calf pol $\alpha$ & Rat pol $\beta$ \\
\hline 1 & $>200$ & $158 \pm 7.8$ \\
2 & $>200$ & $>200$ \\
3 & $>200$ & $>200$ \\
4 & $>200$ & $122 \pm 6.0$ \\
5 & $>200$ & $>200$ \\
6 & $>200$ & $>200$ \\
\hline
\end{tabular}

Compound 1, icosyl cis-p-coumarate; compound 2, docosyl cis-pcoumarate; compound 3, tetracosyl cis-p-coumarate; compound 4, icosyl $p$-coumarate; compound 5, docosyl $p$-coumarate; compound 6 , tetracosyl $p$-coumarate. These compounds were incubated with each pol. Enzymatic activity was measured as described in Materials and methods. Pol activity in the absence of the compounds was taken as $100 \%$. Data are shown as the means \pm SEM of three independent experiments.

activities using aphidicolin, which is a known inhibitor of replicative pols $\alpha, \delta$ and $\varepsilon(29)$, and it selectively inhibited the activity of pol $\alpha$ with an $\mathrm{IC}_{50}$ value of $20 \mu \mathrm{M}$ (30); therefore, compounds 1 and 4 were weaker mammalian pol inhibitors than aphidicolin. When activated DNA (i.e., DNA digested by bovine deoxynuclease I) and dNTP was used as the DNA template-primer and nucleotide substrate, respectively, instead of poly $(\mathrm{dA}) / \operatorname{oligo}(\mathrm{dT})_{18}(\mathrm{~A} / \mathrm{T}=2 / 1)$ and $\mathrm{dTTP}$, the mode of inhibition by these compounds did not change (data not shown).

Effects of alkyl p-coumarates on human DNA topoisomerases I and II. As the secondary screening for DNA metabolic enzyme inhibition, the inhibitory effects of compounds 1-6 were investigated against human topos I and II, which have single-stranded and dsDNA nicking activity, respectively (5). 


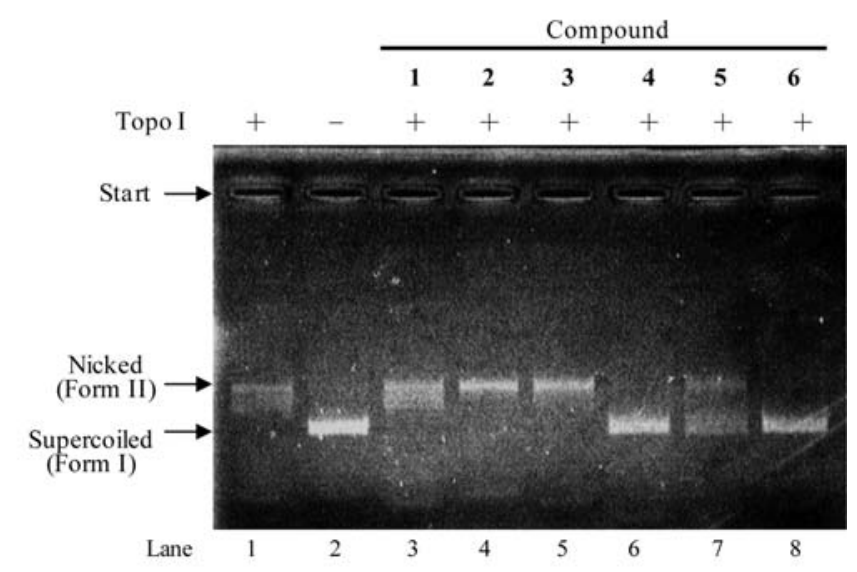

B

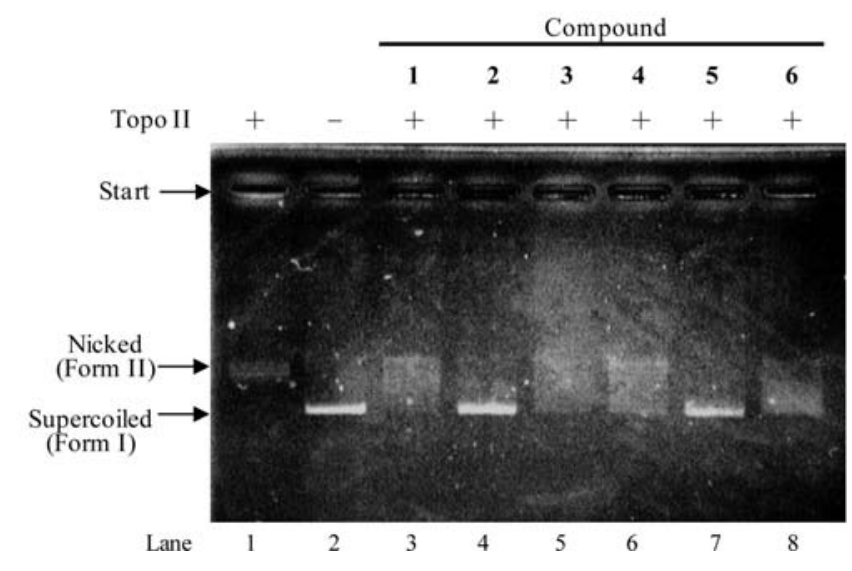

Figure 2. Effect of alkyl $p$-coumarates on human topos I and II. (A) Topo I and (B) topo II. Supercoiled plasmid DNA was mixed with the enzyme and $50 \mu \mathrm{M}$ of compounds 1-6 dissolved in DMSO (lanes 3-8, respectively). Lanes 1-2, no compounds. Lanes 2-8, 2 U of topo enzyme; Lane 2, no enzyme. $0.25 \mu \mathrm{g}$ plasmid DNA was added to each lane. Photographs of EtBr-stained gels are shown.

As shown in Fig. 2A, $50 \mu \mathrm{M}$ of compounds 4-6 inhibited the activity of topo I, but compounds 1-3 did not, suggesting that trans-configuration of the double bond in alkyl side chain of $p$-coumarates, such as compounds 4-6, must be important for topo I inhibition. On the other hand, topo II inhibition was significantly shown by $50 \mu \mathrm{M}$ of compounds 2 and 5, and the other compounds, 1, 3, 4 and 6, were slightly affected (Fig. 2B), suggesting that the C20-alkyl side chain of $p$ coumarates, such as compounds 2 and 5 , must be important for the inhibition of topo II. Compound 5 inhibited the activities of both topo I and topo II, and $\mathrm{IC}_{50}$ values were 30 and $5.0 \mu \mathrm{M}$, respectively (Table II). Camptothecin and etoposide, which are known topo I and topo II inhibitors, respectively, also inhibited the nicking activities of topos I and II with $\mathrm{IC}_{50}$ values of 85 and $70 \mu \mathrm{M}$, respectively; therefore, compound 5 was a stronger topos I and II inhibitor than camptothecin and etoposide, respectively. These findings showed that the mammalian pol inhibitory activity of these $p$-coumarates showed a different tendency from human topo inhibitory activity (Table I and Fig. 2). Furthermore, we studied the inhibitory effect of alkyl $p$-coumarates on human cancer cells.
Effects of alkyl p-coumarates on cultured human cancer cells. Pols and topos have recently emerged as important cellular targets for chemical intervention in the development of anti-cancer agents. Alkyl p-coumarates (i.e., compounds 1-6) could therefore be useful in chemotherapy, and we investigated the cytotoxic effect of six compounds against two HCT116 human colon carcinoma cultured cell lines, which were a wild-type p53 (p53+/+) and deleted mutant of p53 (p53-- ). As shown in Fig. 3, 50 and $100 \mu \mathrm{M}$ of compound 5 had the strongest growth inhibitory effect on HCT116 cells with $\mathrm{p} 53^{+/+}$and $\mathrm{p} 53^{-/-}$in the tested compounds with $\mathrm{LD}_{50}$ values of 33.8 and $31.2 \mu \mathrm{M}$, respectively. The influence of compounds 1-6 on HCT116 p53 $3^{+/}$cell growth showed the same tendency as that on HCT116 $\mathrm{p} 53^{-/}$cells, suggesting that $\mathrm{p} 53$ protein expression had no relation to cell growth inhibition by alkyl $p$-coumarates. In terms of the growth inhibitory effect, the ranking was compound $5>$ compounds 2,4 and $6>$ compounds 1 and 3 . These results suggest that the cancer cell growth prevention by these compounds may be related to the inhibition of topos I and II activities rather than pol activity; in particular, the inhibition of both topo I and topo II by compound 5 must be important for HCT116 cell proliferation. Compound 5 more strongly suppressed the growth of HCT116 $\mathrm{p} 53^{+/+}$and $\mathrm{p} 53^{-/-}$cells than the same concentrations of aphidicolin, camptothecin and etoposide, which are inhibitors of replicative pols, topo I and topo II, respectively (data not shown). Therefore, we concentrated our efforts on compound 5 in the latter part of this study.

Effects of compound 5 on various DNA polymerases and other DNA metabolic enzymes. The inhibition of in vitro DNA metabolic enzyme activities by compound 5 was investigated (Table II). This compound did not inhibit the activities of the various pols tested, mammalian major pols (i.e., pols $\alpha, \beta, \gamma$, $\delta$ and $\varepsilon$ ), plant (cauliflower) pol $\alpha$, prokaryotic pols (E. coli pol I, Taq pol and T4 pol). In the other DNA metabolic enzymes tested, compound 5 inhibited the activities of both human topo I and human topo II, and the inhibitory effect on topo II was 6-fold stronger than on topo I. This compound had no influence on the activities of calf primase of pol $\alpha$, calf terminal deoxynucleotidyl transferase, human telomerase, HIV-1 reverse transcriptase, T7 RNA polymerase, T4 polynucleotide kinase and bovine deoxyribonuclease I. As a result, compound 5 was a potent and selective inhibitor of human topos, especially topo II.

To determine whether the inhibitor resulted in binding to DNA or the enzyme, the interaction of compound 5 with dsDNA was investigated based on the thermal transition of dsDNA with or without the compound. The melting temperature $(\mathrm{Tm})$ of dsDNA with an excess amount of the compound $(200 \mu \mathrm{M})$ was measured using a spectrophotometer equipped with a thermoelectric cell holder. In the concentration range used, no thermal transition of Tm was observed, whereas $\operatorname{EtBr}(15 \mu \mathrm{M})$, used as a positive control, a typical intercalating compound, produced clear thermal transition. These observations indicated that compound 5 did not intercalate to DNA as a template-primer, and this compound may directly bind to the enzyme and inhibit its activity. We investigated in more detail whether topo inhibition by compound 5 is effective for human cancer cell proliferation. 
Table II. $\mathrm{IC}_{50}$ values of compound 5 for the activities of various DNA polymerases and other DNA metabolic enzymes.

\begin{tabular}{lc}
\hline Enzyme & $\begin{array}{c}\mathrm{IC}_{50} \text { value of } \\
\text { compound } 5 \\
(\mu \mathrm{M})\end{array}$ \\
& \\
\hline i) DNA polymerases & $>200$ \\
Calf DNA polymerase $\alpha$ & $>200$ \\
Rat DNA polymerase $\beta$ & $>200$ \\
Human DNA polymerase $\gamma$ & $>200$ \\
Human DNA polymerase $\delta$ & $>200$ \\
Human DNA polymerase $\varepsilon$ & $>200$ \\
Cauliflower DNA polymerase $\alpha$ & $>200$ \\
E. coli DNA polymerase I & $>200$ \\
Taq DNA polymerase & $>200$ \\
T4 DNA polymerase & \\
ii) Other DNA metabolic enzymes & $>200$ \\
Calf primase of DNA polymerase $\alpha$ & $>200$ \\
Calf terminal deoxyribonucleotidyl & $>200$ \\
transferase & $>200$ \\
Human telomerase & 5000 \\
HIV-1 reverse transcriptase & \\
T7 RNA polymerase & \\
Human DNA topoisomerase I & \\
Human DNA topoisomerase II & \\
T4 polynucleotide kinase & \\
Bovine deoxyribonuclease I & \\
\hline
\end{tabular}

Compound 5 (docosyl p-coumarate) was incubated with each enzyme. Enzymatic activity was measured as described in Materials and methods. Enzyme activity in the absence of the compounds was taken as $100 \%$. Data are shown as the means \pm SEM of three independent experiments.

Effects on the cell cycle progression of compound 5. Next, we analyzed whether compound 5 affected the cell cycle distribution of compound-treated HCT116 human colon carcinoma cells with or without the p53 gene. The cell cycle fraction was recorded after $6,12,24$ and $48 \mathrm{~h}$ of treatment with an $\mathrm{LD}_{50}$ value of compound 5, and the ratio of the three phases (i.e., G1, S and G2/M) in the cell cycle is shown in

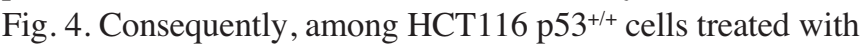
compound 5 for time-dependent incubation, the population of cells in the G2/M phase increased (1.65-fold increase of G2/M phases with 48-h incubation), the ratio of G1 phase of cells was not changed, and the percentage of cells in the $\mathrm{S}$ phase significantly decreased over 48 h (Fig. 4A). Aphidicolin, which is a replicative pol (i.e., pols $\alpha, \delta$ and $\varepsilon$ ) inhibitor, moderately arrested the cell cycle in the $\mathrm{S}$ phase, and etoposide, which is a classical topo II inhibitor, 1.80-fold more strongly arrested the cell cycle in the G2/M phase (data not shown). Compound 5 therefore may be effective in the inhibition of topos for the incubation of cells and halted the cell cycle at
A

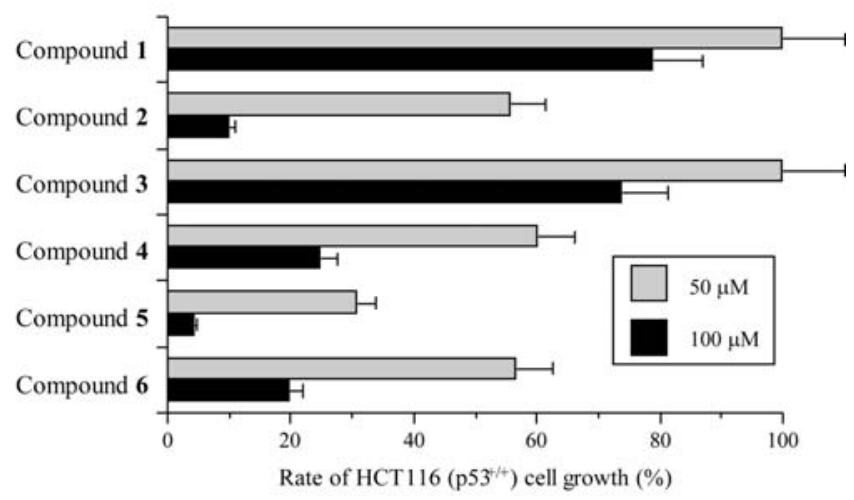

B

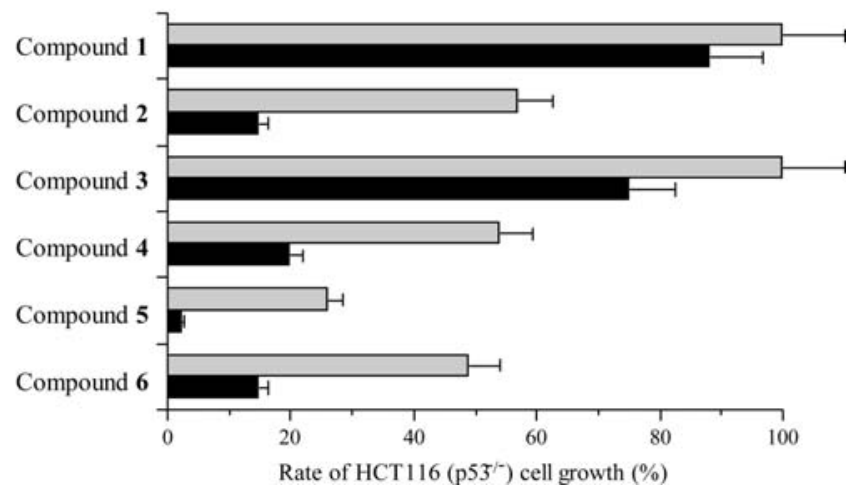

Figure 3. Effect of alkyl p-coumarates on the proliferation of HCT116 human colon carcinoma cultured cell growth. Each compound (50 and $100 \mu \mathrm{M})$ was added to the culture of HCT116 cells with wild-type p53 (HCT116 p53 ${ }^{+/+}$) (A) and their isogenic derivatives that lack p53 (HCT116 p53/-) (B). The cells were incubated for $48 \mathrm{~h}$, and the rate of cultured cell growth inhibition was determined by MTT assay (27). Cell growth inhibition of the cancer cells in the absence of the compound was taken as $100 \%$. Data are shown as the mean \pm SEM of five independent experiments.

the G2/M phase, because this compound selectively inhibited the activities of human topos, and the inhibitory effect on topo II was stronger than that on topo I in vitro (Fig. 2 and Table II). On the other hand, compound 5 did not influence the cell cycle of HCT116 p53/- cells with 48-h incubation (Fig. 5B), suggesting that the cell cycle arrest by this compound must be via the p53-dependent pathway.

Effect of compound 5 on apoptosis induction. The possibility that cell growth suppression by compound 5 may occur through apoptosis was evaluated from caspase- 3 activity, which is a key enzyme activity in the execution of apoptosis mediated by various anti-tumor agents (31). As shown in Fig. 5, the $\mathrm{LD}_{50}$ value of compound 5 also time-dependently increased

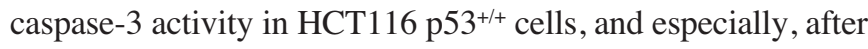
$48 \mathrm{~h}$, caspase- 3 activity increased by $>10$-fold. The findings suggest that compound 5 induced DNA fragmentation and apoptosis in the cells, and the effect of the compound must involve a combination of cell proliferation arrest and cell death; however, when HCT116 $553^{-/-}$cells were treated with the $\mathrm{LD}_{50}$ value of compound 5, caspase- 3 activity was not changed, suggesting that this cell growth inhibition did not induce apoptosis. The apoptosis induction of HCT116 p53 $3^{+/+}$cells 


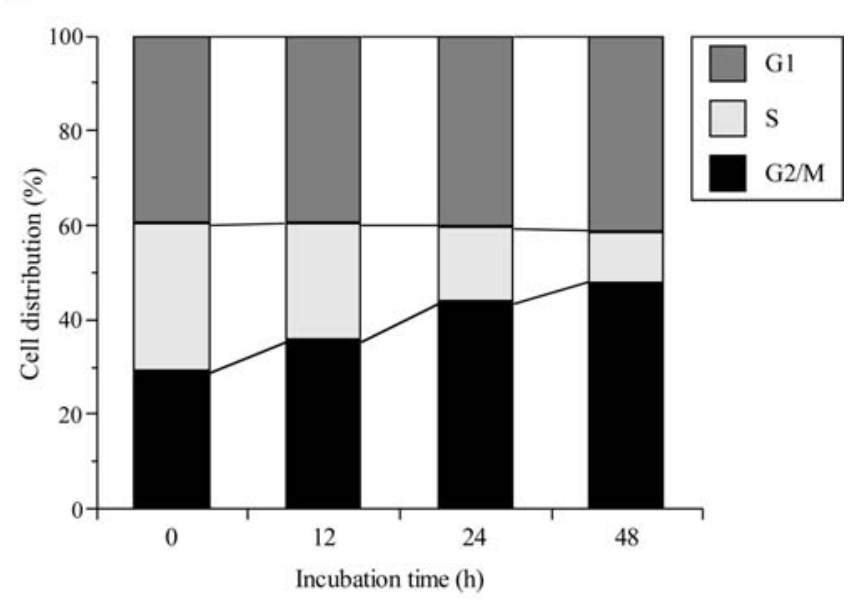

B

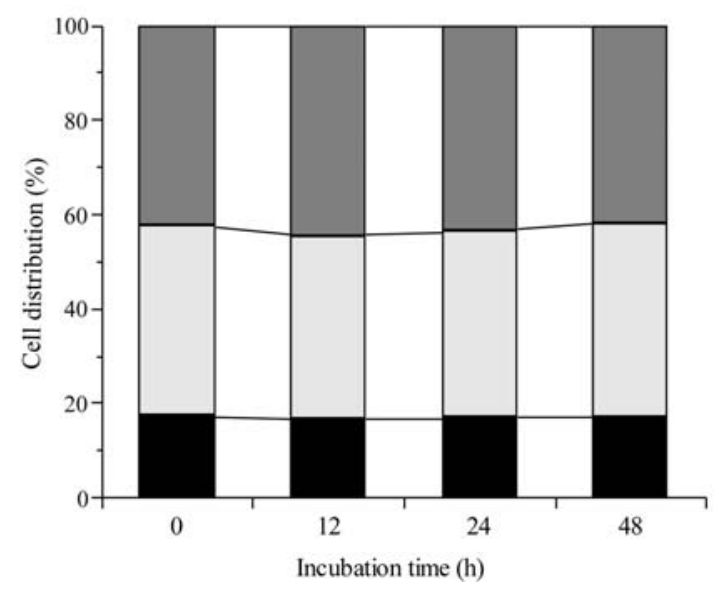

Figure 4. Effect of compound 5 (docosyl p-coumarate) on the cell cycle. (A) The $\mathrm{LD}_{50}$ value of compound $5(33.8 \mu \mathrm{M})$ was added to the culture of HCT116 cells with wild-type p53 (HCT116 p53 $\left.{ }^{+/+}\right)$. (B) The $\mathrm{LD}_{50}$ value of compound $5(31.2 \mu \mathrm{M})$ was added to the culture of HCT116 cells isogenic derivatives lacking p53 (HCT116 p53 $3^{-/-}$). These cells were cultured for 0, 12, 24 and $48 \mathrm{~h}$. Cell cycle distribution was calculated as the percentage of cells in $\mathrm{G} 1, \mathrm{~S}$ and $\mathrm{G} 2 / \mathrm{M}$ phases. All experiments were performed three times.

by this compound therefore must depend on p53 protein. p53 is a tumor suppressor protein and works through several mechanisms, such as DNA repair activation when DNA has sustained damage, cell cycle regulation and apoptosis induction (32); therefore, topo inhibition by compound 5 might be important for anti-cancer function through p53 protein.

\section{Discussion}

As described, we found that some alkyl $p$-coumarates inhibited the activities of DNA metabolic enzymes, such as pols and/or topos, and also suppressed human cancer cell growth (Figs. 2 and 3 and Table I). In particular, docosyl $p$-coumarate (compound 5) may be a potent and selective inhibitor of human topos I and II. The suppression of cell growth had the same tendency as the inhibition of the combination of topos I and II among alkyl $p$-coumarates, suggesting that the cause of cancer cell influence might be the activity of topos I and II. To analyze the cell proliferation and growth of topos in cancer cells,

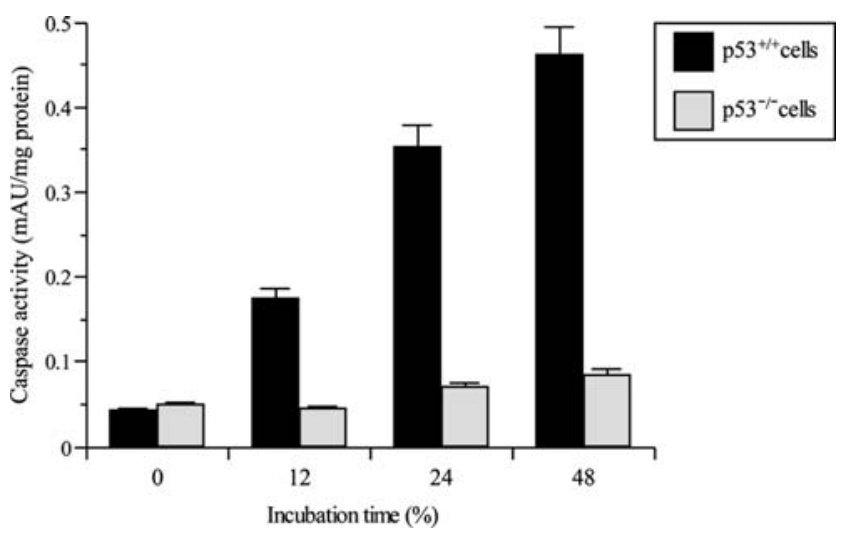

Figure 5. Effect of compound 5 (docosyl p-coumarate) on caspase- 3 activity in HCT116 cells. HCT116 p53 $3^{+/+}$(black bar) and p53 (gray bar) cells were incubated with the $\mathrm{LD}_{50}$ values of compound 5 (i.e., 33.8 and $31.2 \mu \mathrm{M}$, respectively) for $0,12,24$ and $48 \mathrm{~h}$. Data are shown as the means \pm SEM of four independent experiments.

Table III. Clog P-values, calculated pKa values, and molecular length and width of the three-dimensional structure of alkyl p-coumarates.

\begin{tabular}{ccccc}
\hline Compound & CLog P & pKa & Width $(\AA)$ & Length $(\AA)$ \\
\hline 1 & $11.70 \pm 0.30$ & $9.69 \pm 0.15$ & 6.4 & 33.0 \\
2 & $12.80 \pm 0.20$ & $9.69 \pm 0.15$ & 6.4 & 35.5 \\
3 & $13.90 \pm 0.30$ & $9.69 \pm 0.15$ & 6.4 & 38.0 \\
4 & $11.74 \pm 0.25$ & $9.69 \pm 0.15$ & 4.2 & 34.0 \\
5 & $12.80 \pm 0.20$ & $9.69 \pm 0.15$ & 4.2 & 36.5 \\
6 & $13.90 \pm 0.30$ & $9.69 \pm 0.15$ & 4.2 & 39.0 \\
\hline
\end{tabular}

Compound 1, icosyl cis-p-coumarate; compound 2, docosyl cis-pcoumarate; compound 3, tetracosyl cis-p-coumarate; compound 4, icosyl p-coumarate; compound 5, docosyl p-coumarate; compound 6 , tetracosyl $p$-coumarate. Unless otherwise noted, both the Clog Pvalues and $\mathrm{pKa}$ values of compounds 1-6 were obtained from the calculated properties in SciFinder Scholar, which were originally calculated using Advanced Chemistry Development (ACD/Lab) Software V8.14 for Solaris (ACD/Labs). Energy-minimized threedimensional compounds 1-6 were prepared using Discovery Studio (Accelrys, San Diego, CA, USA).

studies on the effects of small interfering RNAs (siRNA) of topos I and II-treated cells are now underway in our laboratory.

We focused on the calculated $\log \mathrm{P}(\mathrm{Clog} \mathrm{P})$ value (partition coefficients for octanol/water) and $\mathrm{pKa}$ (acid dissociation constant) of the alkyl $p$-coumarates as chemical properties (Table III). The values of $\mathrm{Clog} \mathrm{P}$, which indicate hydrophobicity, in compounds 1 to 6 were almost in the same range (11.70-13.90); therefore, the Clog P value had no influence on inhibition. Since pKa values in these compounds also had the same value (9.69), the acidity of compounds must not affect their activities. On the other hand, the molecular length and width of the three-dimensional structure of the 
compounds were calculated. As shown in Table III, the width of cis-type of compounds 1-3 and trans-type of compounds 4-6 was 6.4 and $4.2 \AA$, respectively. Since compound 5 showed the strongest inhibition of topo II activity and HCT116 cancer cell growth, the C20-alkyl side chain length of compound 5 (i.e., $36.5 \AA$ ) might be important for inhibition.

Topo inhibitors, such as adriamycin, amsacrine, ellipticine, saintopin, streptonigrin and terpentecin, are intercalating agents, and were thought to bind to the DNA molecule directly, and subsequently to inhibit both activities indirectly. They inhibited the rejoining reaction of topos by stabilizing a tight topo protein-DNA complex termed the 'cleavable complex'. To determine whether compound 5 binds to DNA, the Tm of dsDNA was measured, and none of the compound was found to bind to dsDNA. Thus, compound 5 must inhibit enzyme activities by interacting with the enzymes directly. Topo inhibitors are categorized into two classes, 'suppressors', which are believed to interact directly with the enzyme and 'poisons', which stimulate DNA cleavage and DNA intercalation (33). Compound 5 may be considered as a 'suppressor' of topo functions rather than as a conventional poison, since this compound does not stabilize topo protein-DNA covalent complexes such as the above-described agents. Compound 5 therefore could be a new type of topo inhibitor.

In conclusion, some alkyl $p$-coumarates containing compound 5 selectively inhibited the activities of animal pol $B$ and human topos I and II, and potently suppressed human cancer cell proliferation with cell cycle arrest and apoptosis induction via the p53-dependent pathway. These alkyl $p$ coumarates, especially compound 5 , therefore should be considered the lead compound in potentially useful cancer chemotherapy agents.

\section{Acknowledgments}

We are grateful for the donations of calf pol $\alpha$ by Dr M. Takemura of Tokyo University of Science (Tokyo, Japan), rat pol $\beta$ by Dr A. Matsukage of Japan Women's University (Tokyo, Japan), human pol $\gamma$ by Dr M. Suzuki of Nagoya University School of Medicine (Nagoya, Japan), and human pols $\delta$ and $\varepsilon$ by Dr K. Sakaguchi of Tokyo University of Science (Chiba, Japan). This work was supported in part by the 'Academic Frontier' Project for Private Universities: matching fund subsidy from the Ministry of Education, Science, Sports, and Culture of Japan (MEXT), 2006-2010 (Y.M. and H.Y.). Y.M. acknowledges a Grant-in-Aid for Young Scientists (A) (No. 19680031) from MEXT.

\section{References}

1. Kornberg A and Baker TA: DNA replication. 2nd edition. W.D. Freeman and Co., New York, pp197-225, 1992.

2. Bebenek K and Kunkel TA: Functions of DNA polymerases. Adv Protein Chem 69: 137-165, 2004.

3. Hubscher U, Maga G and Spadari S: Eukaryotic DNA polymerases. Annu Rev Biochem 71: 133-163, 2002.

4. Takata K, Shimizu T, Iwai S and Wood RD: Human DNA polymerase N (POLN) is a low fidelity enzyme capable of error-free bypass of 5S-thymine glycol. J Biol Chem 281: 23445-23455, 2006

5. Wang JC: DNA topoisomerases. Annu Rev Biochem 65: 635-692, 1996.
6. Chakraborty AK and Majumder HK: Mode of action of pentavalent antimonials: specific inhibition of type I DNA topoisomerase of Leishmania donovani. Biochem Biophys Res Commun 152: 605-611, 1988.

7. Liu LF: DNA topoisomerase poisons as antitumor drugs. Annu Rev Biochem 58: 351-375, 1989.

8. Ray S, Hazra B, Mittra B, Das A and Majumder HK: Diospyrin, a bisnaphthoquinone: a novel inhibitor of type I DNA topoisomerase of Leishmania donovani. Mol Pharmacol 54: 994-999, 1998.

9. Sakaguchi K, Sugawara F and Mizushina Y: Inhibitors of eukaryotic DNA polymerases. Seikagaku 74: 244-251, 2002.

10. Sriram D, Rao VS, Chandrasekhara KV and Yogeeswari P: Progress in the research of artemisinin and its analogues as antimalarials: an update. Nat Prod Res 18: 503-527, 2004

11. Nishimura K, Takenaka Y, Kishi M, Tanahashi T, Yoshida H, Okuda C and Mizushina Y: Synthesis and DNA polymerase $\alpha$ and $B$ inhibitory activity of alkyl $p$-coumarates and related compounds. Chem Pharm Bull (Tokyo) 57: 476-480, 2009.

12. Tamai K, Kojima K, Hanaichi T, Masaki S, Suzuki M, Umekawa $\mathrm{H}$ and Yoshida S: Structural study of immuno-affinitypurified DNA polymerase $\alpha$-DNA primase complex from calf thymus. Biochim Biophys Acta 950: 263-273, 1988.

13. Date T, Yamaguchi M, Hirose F, Nishimoto Y, Tanihara K and Matsukage A: Expression of active rat DNA polymerase $\beta$ in Escherichia coli. Biochemistry 27: 2983-2990, 1988.

14. Umeda S, Muta T, Ohsato T, Takamatsu C, Hamasaki N and Kang D: The D-loop structure of human mtDNA is destabilized directly by 1-methyl-4-phenylpyridinium ion $\left(\mathrm{MPP}^{+}\right)$, a parkinsonism-causing toxin. Eur J Biochem 267: 200-206, 2000.

15. Oshige M, Takeuchi R, Ruike R, Kuroda K and Sakaguchi K: Subunit protein-affinity isolation of Drosophila DNA polymerase catalytic subunit. Protein Expr Purif 35: 248-256, 2004.

16. Sakaguchi K, Hotta Y and Stern H: Chromatin-associated DNA polymerase activity in meiotic cells of lily and mouse. Cell Struct Funct 5: 323-334, 1980.

17. Mizushina Y, Tanaka N, Yagi H, Kurosawa T, Onoue M, Seto H, Horie T, Aoyagi N, Yamaoka M, Matsukage A, Yoshida S and Sakaguchi K: Fatty acids selectively inhibit eukaryotic DNA polymerase activities in vitro. Biochim Biophys Acta 1308: 256-262, 1996.

18. Mizushina Y, Yoshida S, Matsukage A and Sakaguchi K: The inhibitory action of fatty acids on DNA polymerase B. Biochim Biophys Acta 1336: 509-521, 1997.

19. Ogawa A, Murate T, Suzuki M, Nimura Y and Yoshida S: Lithocholic acid, a putative tumor promoter, inhibits mammalian DNA polymerase ß. Jpn J Cancer Res 89: 1154-1159, 1998.

20. Yonezawa Y, Tsuzuki T, Eitsuka T, Miyazawa T, Hada T, Uryu K, Murakami-Nakai C, Ikawa $\mathrm{H}$, Kuriyama I, Takemura $\mathrm{M}$, Oshige M, Yoshida H, Sakaguchi K and Mizushina Y: Inhibitory effect of conjugated eicosapentaenoic acid on human DNA topoisomerases I and II. Arch Biochem Biophys 435: 197-206, 2005.

21. Tamiya-Koizumi K, Murate T, Suzuki M, Simbulan CG, Nakagawa M, Takamura M, Furuta K, Izuta S and Yoshida S: Inhibition of DNA primase by sphingosine and its analogues parallels with their growth suppression of cultured human leukemic cells. Biochem Mol Biol Int 41: 1179-1189, 1997.

22. Oda M, Ueno T, Kasai N, Takahashi H, Yoshida H, Sugawara F, Sakaguchi K, Hayashi H and Mizushina Y: Inhibition of telomerase by linear-chain fatty acids: a structural analysis. Biochem J 367: 329-334, 2002.

23. Ohta K, Mizushina Y, Hirata N, Takemura M, Sugawara F, Matsukage A, Yoshida S and Sakaguchi K: Sulfoquinovosyldiacylglycerol, KM043, a new potent inhibitor of eukaryotic DNA polymerases and HIV-reverse transcriptase type 1 from a marine red alga, Gigartina tenella. Chem Pharm Bull (Tokyo) 46: 684-686, 1998.

24. Nakayama C and Saneyoshi M: Inhibitory effects of 9- $\beta-D-$ xylofuranosyladenine 5'-triphosphate on DNA-dependent RNA polymerase I and II from cherry salmon (Oncorhynchus masou). J Biochem (Tokyo) 97: 1385-1389, 1985.

25. Soltis DA and Uhlenbeck OC: Isolation and characterization of two mutant forms of T4 polynucleotide kinase. J Biol Chem 257: 11332-11339, 1982.

26. Lu BC and Sakaguchi K: An endo-exonuclease from meiotic tissues of the basidiomycete Coprinus cinereus: its purification and characterization. J Biol Chem 266: 21060-21066, 1991. 
27. Mosmann T: Rapid colorimetric assay for cellular growth and survival: application to proliferation and cytotoxicity assays. J Immunol Methods 65: 55-63, 1983.

28. Mizushina Y: Specific inhibitors of mammalian DNA polymerase species. Biosci Biotechnol Biochem 73: 1239-1251 2009.

29. Ikegami S, Taguchi T, Ohashi M, Oguro M, Nagano H and Mano Y: Aphidicolin prevents mitotic cell division by interfering with the activity of DNA polymerase- $\alpha$. Nature 275 : $458-460$, 1978

30. Mizushina Y, Kamisuki S, Mizuno T, Takemura M, Asahara H, Linn S, Yamaguchi T, Matsukage A, Hanaoka F, Yoshida S, Saneyoshi M, Sugawara F and Sakaguchi K: Dehydroaltenusin, a mammalian DNA polymerase $\alpha$ inhibitor. J Biol Chem 275 $33957-33961,2000$
31. Kaufmann SH: Cell death induced by topoisomerase-targeted drugs: more questions than answers. Biochim Biophys Acta 1400: $195-211,1998$

32. Joerger AC and Fersht AR: Structural biology of the tumor suppressor p53. Annu Rev Biochem 77: 557-582, 2008.

33. Christian B: Topoisomerase I poisons and suppressors as anticancer drugs. Curr Med Chem 7: 39-58, 2000. 